Bojan Žikić

\title{
Anthropology of AIDS. Risk environment and injecting routine - the case of Belgrade injecting drug users ${ }^{* 1}$
}

\begin{abstract}
Risk environment is usually seen as physical and social one; first concerns physical space of injecting, while second deals with people who inject and their relations. Injecting routine is designation for set of IDUs habitual life. Management of risk related to $\mathrm{HIV} / \mathrm{HCV}$ is reviewed and discussed after the results of qualitative anthropological research conducted among the Belgrade IDUs , due to establishing, performing and disrupting injecting routines within physical and social risk environments.
\end{abstract}

Key words: HIV/HCV risk management; risk environment; injecting routine; qualitative research; anthropology of AIDS

Risk environment is a theoretical concept, a tool for analysis, which is in reality difficult to distinguish from risk behaviour ${ }^{2}$. It would be the simplest to

* Рад је резултат учешћа у научноистраживачком пројекту Културни идентитети у процесима европске интеграције и регионализације, бр. 147035 који финансира Министарство за науку и животну средину Републике Србије, а истраживање је спроведено у сарадњи са HIV prevention among vulnerable populations initiative (HPVPI) project: qualitative research studies on injecting drug use and sexual work in Belgrade - UNPD, office in SCG \& Imperial College, London. У прикупљању података учествовале су студенткиње пост-дипломских студија на Одељењу за етнологију и антропологију београдског Филозофског факултета: Елена Кунески, Слађана Барош и Ана Продановић.

${ }^{1}$ Research was supported by Serbian Ministry of Science and Environmental Protection Project 147035, and it was carried out conjoined with HIV prevention among vulnerable populations initiative (HPVPI) project: qualitative research studies on injecting drug use and sexual work in Belgrade - UNPD, office in SCG \& Imperial College, London. Research assistants have been employed, the post-graduate students from MA-degree in Ethnology and Anthropology at Belgrade Philosophy Faculty: Elena Kuneski, Slađana Baroš, Ana Prodanović. I also wish to thank dr. Tim Rhodes for advise, support, and supervision in this enterprise.

Етноантрополошки проблеми н.с. год. 1. св. 1 (2006) 
say that risk environment spatialises risk behaviour physically and socioculturally, but this would not help to bridge this, ever existing gap between what has been researched and the way the researched is examined ${ }^{3}$. For example, sharing ${ }^{4}$ is, indisputably, a component of risk behaviour - in reality and as a concept. It does not only occur in risk environments, whether we are talking about space or people; it is conditioned by such environments - perhaps not always, but in a sufficient number of cases for us to say that sharing is also a component of risk environments ${ }^{5}$. It is similar with needles and syringes and for, in principle, each element of injecting drug users ${ }^{6}$ practice - both as observed and as narrated. Therefore, to understand IDU perception of risk and their risk management - and primarily to be able to understand these differences from research perspective, it is necessary to look at physical and social risk environment as $\mathrm{HIV} / \mathrm{HCV}$ risk generating factors.

Physical risk environment is to be understood as the physical space which frames the injecting procedure: it is where scoring ${ }^{7}$ happens. The notion of physical risk environment includes both private and public spaces, no matter whether they are described as indoors or outdoors: rooms, cellars, gardens, graveyards, or public toilets - or in fact wherever IDUs score - serve as a fine example of physical (risk) environment. Well, if it is clear where that "physical" does come from, it should not be obsolete to mention that the notion of risk related to IDU practice is somehow considered as inherent to that practice both by itself and after the circumstances usually involved ${ }^{8}$ in it. Social risk environment deals with people who inject and with various aspects and types of their mutual relations, ranging from their non-IDU social positions, or their

${ }^{2}$ See Tim Rhodes, The "Risk Environment": A Framework for Understanding and Reducing Drug-Related Harm. International Journal of Drug Policy 13, 2002; Scott Burris, Kim M. Blankenship, Martin Donoghoe, Susan Sherman, John S. Vernick, Patricia Case, Zita Lazzarini, and Stephen Koester, Addressing the "Risk Environment" for Injection Drug Users: The Mysterious Case of the Missing Cop, The Milbank Quarterly Vol. 82, No. 1, 2004.

${ }^{3}$ T. Rhodes, op. cit, 85-87.

${ }^{4}$ In this paper, sharing refers to the joint use of injecting equipment, mostly of needles and syringes, by more than one person at the same time.

5 Cf. Tim Rhodes, Merrill Singer, Philippe Bourgois, Samuel R. Friedman, Steffanie A. Strathdee, The social structural production of HIV risk among injecting drug users, Social Science \& Medicine 61, 2005.

${ }^{6}$ Which are further to be referred at as IDU/ IDUs in various contexts.

${ }^{7}$ Terms from Belgrade IDU slang are always print italic when occur for the first time; later, there is no reminder on their sociolinguistic nature.

${ }^{8}$ For details on Belgrade case, see Bojan Žikić, Anthropological Analysis of $\mathrm{HIV} / \mathrm{HCV}$-vulnerability and Risk Behaviour in Belgrade, in Everyday Culture in Postsocialist Period, Zbornik radova Etnografskog instituta SANU 22, Beograd 2006.

Етноантрополошки проблеми н.с. год. 1. св. 1 (2006) 
intra-IDU-world roles, to the effects of their eventual financial sustainability on their drug-related communicative behaviour". Again, while the "social" part of this notion is clear, the determinative one is installed within the IDU practice, i.e. that considering the risk in itself.

So clearly, the common ground for the sole existence of HIV/HCV-related risk within this population is found in their injecting practice. What is considered by the certain type of risk environment is how that risk is produced - the way by which HIV/HCV-vulnerability is achieved most directly: obviously after the physical contact made by some crucial part of injecting equipment with someone's blood, but - be it via the spatial or via the social agency.

Establishing a certain personal injecting routine, whether based on some safety procedure ${ }^{10}$ or not, is in close connection with the risk environment concept. As one could expect, IDUs have preferences concerning the space they inject in, and the crucial thing for them is that the place is safe - both from the view of passers-by or from the possible police raid, but often also from other IDUs. It is clear that such a formulation primarily refers to having one's own living space, but it is also clear that it does not refer solely to physical environment - or, it is not just about the place, than it is maybe more about the way it is used and people using it. Similarly to it being difficult to make a distinction in reality between risk environment and risk behaviour, distinguishing between physical and social risk environment is more an analytical need than a factographic distinction ${ }^{11}$. Physical injecting space is always organised as a reference to the relation of the specified IDU(s) towards other people, in one way or another. It is usually matter of permeability of the space in injecting purposes, i. e. who controls it being used that manner by evaluating people eventually suitable to score at it and letting some of them to do that.

Therefore, if we were to abstract that the concept of physical risk environment relates to the plastic injecting space, and that the concept of social risk environment relates to interaction within a group of people relating to IDU practice and relevant humanly caused interventions outside of it, we

${ }^{9}$ See Rhodes, op. cit; K. E. Poundstone, S. A. Strathdee, and D. D. Celentano, The Social Epidemiology of Human Immunodeficiency Virus/Acquired Immunodeficiency Syndrome, Epidemiologic Reviews 26, 2004; Tim Rhodes, Mark Davis \& Ali Judd, Hepatitis $\mathrm{C}$ and its risk management among drug injectors in London: renewing harm reduction in the context of uncertainty, Addiction 99, 2004.

${ }^{10}$ Safety procedure is analytic descriptive model for the way IDUs behave concerning relation between their knowledge on diseases and their will and ability to protect themselves from those. It is different for almost each person, although the concept could be theoretically generalized after extracting pattern traits from individual behaviours.

${ }^{11}$ Cf. Rhodes, op. cit; Žikić, op. cit. 
could say that one of the research aims was to establish the way in which these environments influence in generating or reducing the risk to $\mathrm{HIV} / \mathrm{HCV}$ among the studied population. The most general starting point for considering this issue is the conclusion that both types of risk behaviour represent a reference system within which individual IDUs form their injecting habits. This does not refer solely to the act of injecting, but to each element of IDU practi$\mathrm{ce}^{12}$, where, of course, physical and social environment do not influence the same elements of this practice in the same way.

So that, for example, social environment will influence the process of obtaining drugs more, while physical environment will put some major stress on storing needles and syringes - although, in a certain way, there will always be also an influence of the social environment on the storage. The latter is the most obvious for IDUs cohabiting with non-IDU people (usually with parents, mostly not approving the injecting habit, of course): IDUs then have to take care not just of the physical environmental factors eventually influencing risk status of their needles and syringes, such as if the storaging place is clear enough not to impose the direct harm coming from dirt upon the equipment, but also to deal with the need of keeping the equipment off the sight and reach of their cohabitants, often willing to destroy it, preaching included.

The most prominent influence of both environments will, of course, be on injecting itself ${ }^{13}$. All these influences, however, are not in themselves the aim of the study, but they become one when considered as risk generating factors and/or its management. Namely, IDU practice habits normally develop in the sense of injecting routine, which in itself can be more or less safe regarding $\mathrm{HIV} / \mathrm{HCV}$, i. e. it could be organised the way more precautious due to possible infection, or in a more careless manner. Whatever may the injecting routines be beside formulating them as habitual set of acts concerning everything

${ }^{12}$ Just to remind: the substance must be purchased, but that is not possible in supermarkets, so firm contacts with reliable people must be established and maintained; it is necessary to find the way of financing the injecting habit, and to claim a space where it could be more or less safely performed - which very often means the need in co-investment in purchasing, followed by co-using the substance; one must posses the injecting equipment - everything required to prepare the substance and to inject it, which brings up the matter of obtaining, keeping and storaging all of that; substance must be prepared for injecting use, that is cooked, then scored, flash-experience is to be relived, and the equipment has to be disposed etc.

${ }^{13}$ Cf. T. Rhodes, op cit; T. Rhodes, G.V. Stimson, N. Crofts, A. Ball, K.L. Dehne \& L. Khodakevich, Drug injecting, rapid HIV spread, and the "risk environment", AIDS 13 (Supplement A), 1999; T. Rhodes, G.V. Stimson \& A. Ball, From risk behaviour to risk environment: assessing the social determinants of HIV associated with drug injecting, in Global network on HIV prevention in drug-using populations, Rockville: National Institute on Drug Abuse, 2001.

Етноантрополочки проблеми н.с. год. 1. св. 1 (2006) 
which is included in injecting drug use practice - and to an observer outside of the IDU setting they may seem chaotic and random, but existing - they mostly go on in constant environments - both physical and social.

It is not the same to inject in one owns room and in sibling's room, for an example, considering the physical aspect of risk environment: place of storage do not match the place of use of needle and syringe, there is usually a procedure providing elementary hygiene of pre-injecting and post-injecting treatment of the injecting equipment which is mostly subtle in its idiosyncrasy and totally depended on feelings of person's safety and comfort, etc. Similarly, due to the fact that almost no one injects entirely alone, it is of extreme importance to obtain the substance, prepare it for use, and to score with somebody who is perceived psychologically acceptable, reliable, safe from being police informer or from being suspected as the virus host etc.

In certain situations, however, disruptions of these routines happen for different reasons, but mainly when financial ability to obtain drug and the urge to inject in order not to get in IDU-crisis do not match. What happens then is that the IDUs improvise searching for safe places to inject, and it is stated that the safe place concept entails a suitable physical and social environment. In such situations IDUs are forced to temporarily change their risk management whether they are trying to adjust to the new forms of risk environments, or trying to ignore them and keep to their habitual risk management procedure: some of them would inject almost everywhere out of passsers-by sight immediately after leaving the dealer's place with just purchased drugs, including not taking care whether they re-use their own needles and syringes or the equipment is somebody else's, or it is new, not mentioning the carelessness if they are doing so together with complete strangers, while some other would try to eliminate some or even all of the disruptive factors in satisfying their need.

Disruptions of injecting routines, which come from, practical-physiological reasons, but highlighted IDUs having to satisfy their need at any cost, are characteristic for such an attitude towards equipment which, in given moments represses taking care of tits hygiene, of whether it has been possibly used before, and sometimes even whose it is, or who used it before. This mostly applies to all elements of injecting equipment, but is the most obvious concerning needles and syringes, when it is eventually also the most $\mathrm{HIV} / \mathrm{HCV}$ harmful: IDUs are in given situations less sensitive to using together any of the elements of the injecting equipment, whichever may be their attitude towards all of them normally. The imperative of satisfying the need for drugs in this way influences not only the dissolution of safety procedure against $\mathrm{HIV} / \mathrm{HCV}$ risk directed towards physical injecting environment, but also safety procedures directed towards social injecting environment.

This conclusion, naturally, the most vulnerably applies when it comes to physical surroundings in which people inject when they are disrupting their

Етноантрополочки проблеми н.с. год. 1. св. 1 (2006) 
personal injecting routines. In these situations, actually, there is most often a lack in every aspect, not only of HIV/HCV risk control, but, a whole injecting safety concept is destroyed, the fragments of which can be seen only in providing elementary secrecy of the physical space in which the drugs will be injected. Being obvious that private living spaces are excluded (there is almost a rule not inject at the place where drug is obtained), these places of routine disruption performances are mostly chosen randomly as opposed to standard shteks $^{14}$ - which are a part of the injecting routine - and they include the shteks discovered by other IDUs or less frequented public places or those segments of residential space which are relatively easy to access, and which are, at least minimally, hidden from view of others - or IDUs see them as such. In such occasions, almost as a rule, the previously stored equipment is not used, according to the principle of keeping it at the place of injecting, because there is none there. Needles and syringes are then carried along, bought in pharmacies on the way, obtained in places where the drugs are obtained or found in places of injecting. The latter means that guns would be literally picked up from the ground and used if there are any at the site chosen for injecting.

To come to the point where injecting routines are being disrupted, they first need to be established, and in order to establish them, it is necessary to go through the phase of initiation into injecting drug use. Under initiation into IDU practice we actually understand the period of injecting between the first injection and one's making their own IDU habits, and this, obviously, is not an unambiguous category; it should be rather understood as a kind of module used, for analytical purposes, to set a type of IDU behaviour, which is mostly, not identical for each individual IDU, except for the fact that they all need to go through it. Initiation into IDU practice is important for the study of risk because it is a period of extreme vulnerability for each individual IDU to any potential danger that comes out of their practice, which also includes $\mathrm{HIV} / \mathrm{HCV}$. Although there are IDUs who claim that, for example, they had been acquainted with the risks of $\mathrm{HIV} / \mathrm{HCV}$ and prepared for managing it even before they started injecting drugs, there is a larger number of those who came into the IDU story, if not carelessly, then at least without sufficient relevant information on the included risk, because of which they were without $\mathrm{HIV} / \mathrm{HCV}$ risk management strategy, or the strategy was mostly unsatisfactory even from the aspect of an average IDU safety procedure.

\footnotetext{
${ }^{14}$ The form "sh" is used as a kind of the spelling suggestion, because the original term is štek, which of course hardly gives a clue to someone not acquainted with Serbian diacritics. Shtek is a place where IDUs inject regularly when they have no possibilities to do so within some private space, for whatever reason. It is mostly the cellar of some residential building, but this kind of physical environment sometimes includes desolate buildings, abandoned factories, even semi-exposed constructions of bridge foundations etc.
}

Етноантрополочки проблеми н.с. год. 1. св. 1 (2006) 
There are many accounts reporting sharing - at least the way it is determined here - on the occasion of first injection and during the period of initiation into injecting drug use. It goes from simple multi-person use of a single gun in a total awareness of eventual consequences of such act, to the convictions that if someone was not infected for the first time one shared with him/her, he/she remains that status in a certain period of time and is acceptable to be shared with. In all of these cases, there is an obvious absence of any real perception of risk - which could in itself be considered a truism if it were not for the fact that those starting with injecting drug use were not doing so usually with more experienced IDUs, and that even those older IDUs did not manage the risks of blood transmitted diseases. Such examples show the influence of social risk behaviour on at least two levels. In the first place, it is the influence on forming the habits, which is assumed as the influence of the social environment: namely, the closest social environment, that is, the people they are injecting with - both the ones of similar IDU experience as the initiate and those with longer experience - are, at that moment, the whole IDU world for the beginner. They serve both as a frame of reference and as direct role models, and with it comes the fact that they serve as the direct model for forming their own IDU behaviour by correcting and harmonising it with this model, learned at the time as the model of IDU behaviour.

Another level of influence of a risk social environment on an individual IDU is the level of information: previous examples show a complete lack of any communication about the risk of IDU practice on HIV/HCV in certain period of somebody's IDU career. Under these circumstances it is in fact impossible to create any perception of risk, at least in the sense of a basic security alarm, and this subsequently makes the change in IDU habits more difficult when it comes to adopting a safer injecting routine, which is also a habitual manner in IDUs lives, and which is customary in nearly compulsory way after the initial period of ID using. The real consequence, and a truly unfavourable one to $\mathrm{HIV} / \mathrm{HCV}$ risk management, is getting used to injecting together with another people. At first it is literally injecting together - several people using the same equipment, therefore what we have marked as sharing - and after a certain period of time, it need not be more than using own equipment, but in situations when a larger number of people are injecting. It can even be the habit of scoring either with several other people or with strangers.

It can be concluded from the available information that sharing, in one way or another, in similar situations is much more frequent and probable, than if the injecting routine excludes actions like scoring with several people or strangers, even when IDUs claim they mostly have their own equipment on these occasions - which is also the matter evolving with elaboration of a single injecting routine and progress of its safety procedure as time pass by. The risk here does not only come from sharing as such, but also from the fact that 
equipment is shared with people who do not fall under the categories of permanent injecting partners, who are risk safe, etc. In other words, with a created habit unlike with adopted injecting routine, there is no HIV/HCV risk control strategy: checking the people to at least cook with ${ }^{15}$, if not even inject with is not considered by "ordinary" IDUs, and quite often there are no precautions as to whether (someone's) equipment which is obtained on the spot is really new, or unused.

The last is especially true when one happens in shtek he/she uses as a regular injecting site, but without injecting equipment, which is somehow the case between the routine and its disruption. Then person is not so seldom keen on using the gun first at the reach, with the excuse of "that must be mine, I just left it here", although the notorious fact within IDU-world is that there are hiding places for needles and syringes at regular shteks, just as a way of managing the blood-transmittable diseases risk by protecting one's own equipment from the physical contact to whoever or whatever may endanger it in that manner.

Finally, the lack of perception of social risk environment leads also to a lack of perception of physical risk environment. Getting used to an injecting routine that does not include $\mathrm{HIV} / \mathrm{HCV}$ risk safety procedures also involves a simplified notion of a safe place for injecting: nothing else is taken care of but securing such injecting space where the IDU will be hidden from unwanted view or from possible police raid. In these situations the hygiene of the physical surrounding becomes irrelevant, which directly influences generating risk on blood infections also in view of possible equipment storing in these places, but also when it comes to those critical moments before and after injecting, when the gun is put down. Even though there are no cases recorded where informants played the leading role, but examples are mentioned in which they were witnesses when someone would just take the first syringe they saw in a discovered shtek, in order to fix up, which is a bit encouraging detail concerning the implication that $\mathrm{HIV} / \mathrm{HCV}$-related risk management is immersed in dominant IDU discourse.

Establishing an injecting routine actually means establishing certain habits - or: personal preferences - relating to IDU practice. Although this also relates to the way of acquiring drugs and the way of storing equipment and the act of injecting itself, each IDU creates their own routine according to two parameters: where they inject and who they injects with (if it is not something that they really do alone, which is really very seldom, as already mentioned). These two parameters, naturally, coincide with theoretical concepts of physical risk environment and social risk environment: what IDUs take into account

\footnotetext{
${ }^{15}$ Cooking is part of the preparing procedure: obtained substance has to be merged with water and brought to boil in order to be injected.
}

Етноантрополошки проблеми н.с. год. 1. св. 1 (2006) 
when they evaluate and choose physical space and people they consider suitable for the needs of their practice is the level of safety in relation to all that threatens both this practice and themselves, and this includes the possibility of HIV/HCV infection - but we should not forget that they need not necessarily be guided by this as the basic risk ${ }^{16}$. The accuracy of this judgement is the qualitative measure of the success of their safety procedures, which primarily interest us in those aspects relating to HIV/HCV risk management.

Therefore, however the injecting routine may be established, it includes using relatively standard injecting spaces and people involved in it. Regardless of the fact that there are no strict rules, corresponding, for example, customs and rituals in traditional cultures, IDU practice is, in some ways "ritualised", in the sense that each IDU tries to make an optimal balance between, for example, the amount of heroin they need for a certain period of time, then financial and spatial possibilities for satisfying this need, with each of them trying to, when the drugs were once purchased, avoid carrying them around, but inject them as soon as possible. It has already been mentioned that going to score rarely includes injecting in the space where the drugs were purchased: dealers' safety procedures against the police ask for meetings outdoors rather then seeing them in their dwellings, which is the reason why injecting at the place of purchase is not a common practice.

Dealers' notions of safety obviously do not exactly match those of the IDUs. Their primary concern is police, while IDUs perceivement of safety is far a bit complex q.e.d. Anyway, this is another fine example of how factors described by the concept of social environment influence personal injecting habits, being in fact non-related to the sole act of injecting, but affecting the complete procedure and consequently the lives of IDUs.

On the other hand, as the equipment is not carried around even when not injecting in someone's house - again because of possible troubles with the police - needles and syringes are kept in injecting places (including houses). Therefore, while one factor from the so-called outer social environment - the one outside of the IDU setting - directly influences the forming of IDU risk environments, both physical and social, concerning both injecting itself and keeping needles and syringes, another such factor does this indirectly: first referring to police relation towards IDU practice, and second on habits concerning treatment of basic injecting equipment, resulting from the long lasting uncertainty with obtaining it. Finally, another general condition forming risk environments immanent to IDU practice should be added and it has already

${ }^{16}$ Some of them are more afraid of being jailed, for an example, while for some other the greatest risk is that of eventual exposure before their immediate non-IDU social environment; all such perceptions of risk are also strong motives in personal IDU routine guidance.

Етноантрополошки проблеми н.с. год. 1. св. 1 (2006) 
been mentioned - the inability to adequately satisfy the need for heroin in time and the approaching withdrawal symptoms, which is most often the factor directly influencing the destruction of individual injecting routines and becomes the greatest risk generator with both physical and social IDU practice environments.

Applying qualitative researching methods of anthropology to study of hidden populations within the contemporary society proves feasible whenever the aims of such enterprises are directed towards the conclusions of academic analytical values, or towards some applicable engagement beyond purely academic interests. This particular presentation is part of the attempts of the latter kind, but it nevertheless portrays certain aspect of Belgrade IDU world in an ethnographic manner, also offering some basic levels of explanations inherent to social sciences: the contextual as well the relational ones. The management of risk related to possible infections by HIV and HCV among the Belgrade IDUs is reviewed and discussed after featuring some relevant framework within which the notions of such risk are formed. The basic analytic standpoints are found in the concepts of risk environment and of injecting routine. The first concept comprises different but somehow interlacing sub-concepts of physical and social risk environment, while the latter one is best to be understood when discussed together whit its conceptual anti-thesis, the one of routine disruption. The versatility of situations from IDU-life enabled to be discussed theoretically by employing these concepts provides firm ground for conclusions on how risk management is influenced and formatted by factors both internal and external to personal drug-injecting habits.

It is true that safety procedures - concerning HIV/HCV-related risk as well as any other things IDUs fear of - appear as set of individual products of idiosyncrasy when research data is glanced, but when thoroughly examined, there are observable patterns of the ways they are governed in order to meet the demands of avoiding situations eventually dangerous for getting infected by blood diseases, for example. They always include some management of hygiene of injecting equipment, injecting site, and co-injectors - this way or another. Attempts to control the physical space of injecting, as well the persons suitable to use it, are also always present in IDUs' coping to maintain their safety and health status, save when their routines are being disrupted. And being there, factors causing the routine disruptions also appears as kind of a standard, taking into account that they as a rule emerge when there is no other way to satisfy the urging need, but to inject as soon as possible and anywhere one happens to be at the time, not mentioning that the sole cause for situations like that lies predominantly in momentarily financial deprivation.

Alas, anthropology could not offer neither the clue nor the cure for resolving the real-life social and cultural controversies imposed by existence of injecting drug use, although it is strongly deployed as extremely helpful tool

Етноантрополочки проблеми н.с. год. 1. св. 1 (2006) 
in building the strategies of harm prevention and reduction ${ }^{17}$. Its value remains within the domain of validity and relevance of its research results, which is the goal easiest to achieve by performing qualitative fieldwork studies immune to theoretical disputes of worthiness of the notions like "reality", "informants" or so. This is especially true concerning issues like AIDS ${ }^{18}$, where applicability of discipline is firmly joint to its fieldwork capacities, where theoretical interpretative conclusions perhaps could not stand by themselves no more without their potential value in social engagement, i.e. socio-epidemiological one.

\footnotetext{
${ }^{17}$ Cf. Stephen Koester, The Process of Drug Injection: Applying Ethnography to the Study of HIV Risk Among IDU's, in Tim Rhodes and Richard Hartnoll (eds.), AIDS, Drugs and Prevention, London: Routledge, 1996; Philippe Burgois, Anthropology and epidemiology on drugs: the challenges of cross-methodological and theoretical dialogue, International Journal of Drug Policy 13, 2002.

${ }^{18} \mathrm{Cf}$. Stephanie Kane and Theresa Mason, AIDS and Criminal Justice, Annual Review of Anthropology Vol.30, 2001.
}

Етноантрополошки проблеми н.с. год. 1. св. 1 (2006) 
Антропологија AIDS-a. Ризично окружење и рутина инјектирања међу београдским интравенским корисницима дроге

Ризично окружење је теоријски концепт који се састоји од физичког и социјалног окружења; прво се односи на пластичност простора у којима се редовно обавља интравенско коришћење дроге, док је друго ознака за разматрање људи и њихових односа у контексту дате праксе. Рутина инјектирања представља целокупност навика интравенских корисника дроге у погледу њихове праксе, што очигледно, између осталог, укључује и коришћење одређених простора у дате сврхе, као и социо-културну комуникацију у погледу истога. У раду се, на основу резултата квалитативног антрополошког истраживања, разматрају утицаји основних типова ризичног окружења на установљавање, спровођење и прекидање рутине инјектирања - са аспекта одговарајућих покушаја управљања ризиком од ХИВ и ХЦВ од стране интравенских корисника дроге.

Bojan Žikić

Une anthropologie du SIDA. L'environnement à risque et la routine des injections parmi les usagers de drogues intraveineux à Belgrade

L'environnement à risque est un concept théorique qui se réfère à la fois à l'environnement physique et social; par environnement physique, il faut entendre l'espace dans lequel on pratique régulièrement l'usage intraveineux de stupéfiants; quant à l'environnement social, il renvoie à l'observation des personnes et des relations qu'elles établissent dans le contexte de cette pratique. La routine des injections comprend la totalité des usages qui déterminent les pratiques des usagers de drogues par voie IV; ces usages régissent, notamment, l'utilisation de certains espaces et la communication socioculturelle. Basée sur des résultats obtenus grâce à une recherche anthropologique qualitative, cet article examine l'influence exercée par les principaux types d'environnement à risque sur la mise en place, la poursuite, et la suspension de la routine des injections. L'article s'intéresse de près aux tentatives faites par les usagers de drogues intraveineux en vue de gérer les risques du VIH et du VHC.

Етноантрополочки проблеми н.с. год. 1. св. 1 (2006) 